\title{
Learning Outcome Increase of Two-Dimensional Figure Circumference and Wide Through Touch Media
}

\author{
Siti Hartati ${ }^{*}{ }^{1}$, Ruminiati ${ }^{1}$, Lia Yulianti ${ }^{1}$, Bill Atweh ${ }^{2}$
}

${ }^{1}$ Graduate Program of Elementary Education, Universitas Negeri Malang, Malang, Indonesia.

${ }^{2}$ Science and Mathematics Education Centre, Curtin University of Technology, Perth, Australia.

\begin{tabular}{l|l}
\hline \multicolumn{1}{c|}{ A R T I C L E I N F O } & \multicolumn{1}{c}{ A B S T R A C T } \\
\hline \multirow{2}{*}{$\begin{array}{l}\text { Received: 09-03-20I7 } \\
\text { Revised: 08-05-20I7 }\end{array}$} & $\begin{array}{l}\text { This study aims to improve the learning outcome increase of two-dimensional figure } \\
\text { circumference and wide of the fourth-grade students through touch media. This } \\
\text { study is a classroom action research and conducted in grade IV D at Sabilal } \\
\text { Muhtadin Islamic Elementary School, Banjarmasin academic year 20I7/2018. The } \\
\text { research subjects were 3I students in total. The research result shows that the } \\
\text { Keywords: }\end{array}$ \\
$\begin{array}{l}\text { Learning outcome, two- } \\
\text { dimensional, } \\
\text { circumference }\end{array}$ & $\begin{array}{l}\text { D students can be developed very well. It is shown by the average test result of } \\
\text { media is used in order to to improve student learning outcomes. }\end{array}$ \\
\cline { 2 - 3 } & $\begin{array}{l}\text { C 2018 The Authors. Journal of K6, Education, and Management (j-K6EM). ISSN: 2580-2135. } \\
\text { Published by Graduated Program of Educational Management, Universitas Lambung } \\
\text { Mangkurat, Banjarmasin, Indonesia. This is an open access article under the open journal } \\
\text { systems. }\end{array}$ \\
\hline
\end{tabular}

*Author correspondence: Siti Hartati; E-mail: sitihartati@gmail.com 


\section{Introduction}

Problems of mathematics learning occurred at Islamic Elementary School Sabilal Muhtadin, Banjarmasin in general is students are afraid and have difficulty when they face math lesson. It occurs because probably they have unpleasant experience when studying mathematics in the previous class (Hudojo, in Ariani 2016). Students find difficulty to understand the concepts and formulas in mathematics. This is because the use of media that is not interesting to find the origin of a formula for example is to determine the twodimensional figure circumference and wide. Students are also not directly involved in understanding and discovering the origin of twodimensional figure circumference and wide formula. Many students ask what the use of mathematics in daily life is. Furthermore, it occurs especially on the two-dimensional figure circumference and wide concepts. Students do not realize that their daily activity always involves mathematics. As there is no concrete example in learning, the students do not understand the learning purpose. This is like what is listed in NCTM (National Council of Teachers of Mathematics 2000) that mathematics learning is not a collection of separated material, although it is often given separately.

Based on the preliminary study conducted by researcher at Sabilal Muhtadin Islamic Elementary School Banjarmasin on Monday and Tuesday, August 28 and 29, 2017, it is found that in Grade IV D learning process, especially mathematics, students are less active and cannot learn with a pleasant atmosphere. Learning only focuses on Student Worksheet of a publisher, assess the issues already available in the Student Worksheet without considering the student ability in depth or performs reflection on the lesson. If there are students who score less than the Minimum Mastery Criteria, they are required to work on the remedial available in Student Worksheet. In this case, students have not been able to think critically and relate between the concept of two-dimensional figure circumference and wide with an existing formula. Students have not been able to use the knowledge they acquired before on determining two-dimensional figure circumference and wide concept in determining two-dimensional figure side. Based on that definition, the researchers conclude that students have a problem in identifying the issues, recognizing, and reversing the existing formula on two-dimensional figure circumference and wide concept.

Based on the preliminary study, the researchers need to conduct a research on how to improve Grade IV D student learning result on twodimensional figure circumference and wide concept at Sabilal Muhtadin Islamic Elementary School Banjarmasin. According to Siregar (2014), learning is to gain an understanding as it will be more meaningful in what is learned. The average age of Grade IV D students is IO - II years old. According to Piaget in Susanto (2015), in this stage, thinking process is directed in the real event observed by a child. The child can perform a rather complex problem operation as long as the problem is concrete and not abstract. From Piaget's opinion, the researchers try to use manipulative objects as a medium to concretize two-dimensional figure circumference and wide concept to make it is understood easily by Grade IV D students.

Based on the explanation, it is necessary to implement participative, active, innovative, creative, effective and enjoyable learning process that can build a good emotional relationship between learners and educators, create a setting that able to affect the learning process. The availability of interactive learning media as well as the role of educator as facilitator in order to build an atmosphere are also able to trigger student learning outcome. To create an innovative, effective, interactive, and fun learning process, it is necessary to use the media served as one of the strategies that can be expected to improve student learning outcome (Musfah, 2015).

Related to the learning outcome improvement, a teacher is required to design a learning medium related to the material to be taught and it must involve the students directly in understanding and finding the two-dimensional figure circumference and wide, so that students can receive teaching materials and implement it to their lives. Touch media or manipulative media is all kinds of materials that can be manipulated by hand, rotated, held, reversed, moved, arranged, organized or cut (Dienes, in Hanah, 2016). Furthermore, Muhsetyo in Perdana (2014) describes that manipulative material serves to simplify difficult concepts, present relatively abstract material becomes more 
real to be observed, explain the definition or concepts more concretely, explain certain properties related to counting, fractional and geometry figures characteristic, and display the facts.

Arsyad (2013) said that the message abstract level will be clearer when the message is implemented in the form of symbols such as figure, graphic, or word. If the message is presented in such symbols, only the sense of sight and hearing that can be used to interpret it. Although the level of physical participation decreases, imaginative involvement grows and develops. In this research, the researchers use touch media in the form of used cardboard and children's toys with a shape like a two-dimensional figure and simple material that is easy to obtain in learning mathematics with sub material of "calculate rasterized two-dimensional figure circumference and wide". The used cardboards and simple materials are used as they are easy to obtain, do not require large fund, and easy to implement in several two-dimensional figure models.

Learning outcome is a goal of learning activity. Learning outcome is the skill that a child acquires after learning. Students who succeed in learning are those who successfully master the expected competencies. According to Benyamin S. Bloom's opinion (Ministry of National Education Directorate General of Elementary and Secondary Education Directorate of Primary School Development, 2017) states that the three domains of learning outcome are cognitive, affective, and psychomotor. Furthermore, it can be explained that the cognitive domain (thinking) is related to the intellectual learning outcome (mind processing) from simple to complex. This study aims to discover student learning outcome by using touch media.

The stages of touch media use were: prerequisite material presentation about two-dimensional figure circumference and wide by using touch media, so that students felt more interested and eased in the process of receiving material. The next stage was game using the exercises in Student Worksheet and it was conducted together, presented, and discussed with teacher using touch media. The next stage was quiz stage that was also modified by the researchers with limited time to play simultaneously to avoid the noise. Last, the achievement stage was conducted based on the points obtained at the quiz stage.
The research that mostly inspires the researcher to use manipulative media is Hanah (2016) research, which states that learning action using manipulative material with Realistic Mathematics Education approach can be said successful to comprehend the probability to grade VII at Public Junior High School 26 Malang. It is characterized by the fulfillment of all success criteria of research in cycle II. Based on the learning observation result, student and teacher activity observation in cycle I and cycle II are in good category. Based on the interview result of cycle I and cycle II, student responses to learning is categorized as good.

\section{Methodology}

The research type used was classroom action research to improve learning process quality performed by teacher. It was in line with Arikunto's opinion (20I0) as follows, CAR aimed to improve and enhance the teacher professional service in handling class during the learning process. In this study, the researchers used action research method by Kemmis and Mc Tagart. This method consisted of four components namely planning, action, observation, and reflection, and all the four components were one cycle (Susilo et al., 20I2).

This study was conducted by two cycles in 4 learning in each cycle in grade IV D at Sabilal Muhtadin Islamic Elementary School Banjarmasin, academic year 2017/20I8. The total subjects were 3I students, consisted of I3 male students and I8 female students. The research factors observed were teacher, student, and student learning outcome. The learning outcome indicators observed on student was the intellectual ability (mind processing) from simple to complex. Bloom in Minister of Education and Culture (2017) classified cognitive goals in six levels, namely knowledge, comprehension, application, analysis, synthesis, and evaluation. In addition, Anderson and Krathwohl (200I) revised these six levels of cognitive objectives into recall, understand, apply, analyze, evaluate, and create, and later it was better known as Bloom's taxonomy revision. The learning outcome measured in this classroom action research was CI to C4 through C4 in Bloom's taxonomy, which was the student success in achieving Minimum Mastery Criteria. 
The research data included validation of learning media and research instrument from the validator, teacher and student observation result data from the observer, and test result at the end of action. Then, the data was analyzed by steps according to Mills and Huberman consisted of reduction, presentation, and conclusion of data. The data was collected by using instruments including the learning implementation sheets of teacher and student and cognitive test result. Observation was conducted to obtain data on research subject including the level of student learning activity implementation. It was also conducted with the help of the observer or teacher partner. The structured essay tests were used to obtain research data on learning outcome.

Data analysis was conducted after all data was collected and it consisted of three stages, namely: (I) reduce the data including completion, simplification, and classification. This activity was conducted by summarizing, disposing of unnecessary data, and organizing according to the research problem. (2) Data presentation was conducted after data classification according to its type in accordance with research problems. Data presentation was conducted by organizing the data that had been reduced, to obtain the information about the research process. (3) Drawing conclusion was conducted based on the data presentation by interpreting the meaning of all findings occurred during the action in accordance with the research target.

Student learning outcome success indicator in learning activities was when the student classical learning mastery reached $\geq 80 \%$ of the total Grade IV D students at above Minimum Mastery Criteria.

\section{Results and Discussion}

The research results indicate an increase in learning activity. In the initial condition, the number of active students was I0 students (32.25\%). In cycle I, the number of active students was 2I students, or it was still at $67.74 \%$, and it increased by II students $(35.42 \%)$. These results were categorized poor in this research criteria where $\leq 75 \%$ was categorized as good activity criteria. In cycle II there was an increase in student learning activity, and it was categorized as quite high and reached good criteria $(22.58 \%)$ in this research. In cycle II, the number of active students reached 28 students $(90.32 \%)$. It was because the students had already had learning experience on touch media application in the previous cycle.

Along with the increasing student activity, it can be ascertained that the student learning outcome of mathematics on two-dimensional figure material also increased. Learning outcome before the research was conducted from the document of mathematics score on two-dimensional figure material at the beginning of the previous semester of 2016/2017 academic year. The students who mastered only reached $29.03 \%$ (9 students) from 3I students. If it is compared with research result in cycle I, the learning mastery increased to $58.06 \%$ (I8 students), but it had not been mastered yet from this study ( $\geq 80 \%$ of students complete). In cycle II, it increased again to $83.87 \%$ (26 students) and the percentage was considered mastered from this research. The increase in learning outcome indicates that student is getting better in understanding two-dimensional figure circumference and wide material.

In this study, the researcher role was as organizer assisted by two fellow teachers as observers in charge of observing the learning implementation in class. During the research, the researchers collaborated and always coordinated with the two teachers about learning implementation by using touch media on two-dimensional figure circumference and wide. The researchers always ask for advice to the two teachers as the research colleagues to find ways so that the touch media used by researchers could be applied optimally.

This study subjects were students with an average age of IO - II years old. According to Piaget in Hergenhahn (2008), in this stage the thinking process is directed in concrete events observed by children. Arsyad (2013) said that according to Burner three levels of learning experience, the learning outcome of a person is obtained from direct experience (concrete), reality existed in environment of someone's life, and artificial objects up to the verbal symbols (abstract).

Learning implementation by touch media consisted of two cycles. Cycle I consisted of four meetings and cycle II consisted of three meetings. The stages in cycle I consisted of: planning, execution, observation, evaluation, and reflection. Planning in cycle I was conducted by arranging learning tools including syllabus, Lesson Plan, 
Student Worksheet, cognitive test instrument, observation sheet of teacher and student activity in learning. Planning in cycle I was also conducted by the task division between researchers and fellow teachers or observers. Researcher worked as an instrument organizer, action designer, action executor, analyzer, data interpreter, and research report maker. The observer worked to fill out the observation sheet of teacher and student activity in learning. In general, learning in this study was divided into three activities, namely opening activity, main activity and closing activities.

Student learning activities are activities involving the physical and mental activity of students, facilitated by teachers who supported a successful learning. Sardiman in Sarnoko (2016) also agrees with the statement above. In learning activities, these two activities are interrelated. Learning activity is very important for students, because it provides an opportunity for students to experience and meet the object being studied as best as possible. Learning process requires activity because in principle, learning is conducted to change behavior. In this case, the media plays an important role in improving learning outcome by improving student role in learning. This is in line with Briggs's opinion in Ariani (2013) that media are all tools to stimulate students to learn. On the other hand, Usman (2002) states that learning media according to National Education Association (NEA) is things that can be manipulated, viewed, heard, read, or discussed, and used properly in teaching and learning activity, and affect instructional program effectiveness.

Likewise, effort to improve learning result requires an effective and efficient form of learning, such as choosing media that suits the ability and need of students as well as planned goal. Learning activities can be realized using media learning that can bring student activity and creativity in learning, involve the student actively to obtain the best learning outcome. Learning by using media can encourage students to participate and play an active role in learning process from initial activity, core activity, and up to closing activity. Two-dimensional figure circumference and wide is identical with formula, so the grade IV students must feel dizzy and bored especially on how to reverse the formula. The use of touch media aims to make students to be more active in knowing and finding the formula of twodimensional circumference and wide. Therefore, learning the use of appropriate touch media not only facilitates the students in understanding twodimensional figure and its formula, but it also can be used to practice the rational thinking skill, and the reflective and active thinking skill of students.

During the learning, an observation on teacher and student activity implementation in learning was conducted. Based on the observation result of teacher activity in learning, it obtained the average percentage of 84.90 . This was due to the several stages of learning activities at meeting I were not all implemented. This also occurred in student activity and the average of student activity percentage was 82.75 .

Data analysis conducted on cognitive learning outcome indicated that classical mastery percentage was $63.12 \%$ and the class average was 74.68 . Based on the results of observation and evaluation during cycle I, there were several important things needs to be considered and improved for action plan in the next cycle. Points needed to be improved including: teachers have not been able to motivate students optimally in using touch media especially in the opening meeting. Therefore, in cycle II implementation, teachers should be more intensive in improving student motivation. Students still do not understand the game rules in learning by touch media, mainly in the stage of reversing the formula. Students still confuse, as a result the class atmosphere becomes rowdy when students on stage of reversing the formula. In cycle II, the teacher gave a note about the implementation of such activities a day before learning using touch media.

Based on cycle I implementation reflection result, the action plan in cycle II was as follows: prepared cycle II learning tools consisting of syllabus, Lesson Plan, Student Worksheet, test instrument of cognitive learning outcome, and tools containing steps of learning stage of reversing the formula with touch media given to students. The activities during cycle II were divided into three meetings with a time allocation of $2 \times 35$ minutes.

Student learning outcome appears from the average score of cycle final test. In Cycle I, the average score of student final test was 69.73. In cycle II, it increased by II.37 to 8I.00. Based on the data analysis result of teacher and student activity observation, interview, and cycle final test, it can be concluded that learning with touch media can improve student learning outcome on twodimensional figure circumference and wide. 
Student learning outcome improvement from cycle I to cycle II was very likely to occur because in conducting learning activity from meeting to meeting, both teacher and student make change and improvement each other. So, after using touch media in learning, the more touch media benefits to be gained. Based on this reason, it can be stated that cognitive learning outcome increase is because of action or applied learning process and not because of material difficulty level. In the data, we can see the improvement result from cycle I to cycle II that is indicating the expected learning outcome in applying touch media.

\section{Conclussion and Recomendations}

In the initial observation, student activity in the class still looked passive. After the use of touch media, student activity increased. Students feel happy and enthusiastic in following the learning. Furthermore, it was added and combined with quiz. In Cycle I and II, the researchers used touch media that was mostly made by the teacher and students. Touch media was made from used cardboard, child toys, and simple materials that were easily obtained in mathematics learning with sub material "calculate two-dimensional figure circumference and wide". The use of cardboard and simple materials as touch media also do not require large funds, and easy to apply in several two-dimensional figure models. In the initial condition, the number of active students reached I0 students (30.26\%). In cycle I, the number of active students reached 2I students, or the student learning activity was still at $67.74 \%$, an increase of II students $(35.42 \%)$. These results were categorized poor in this research criteria where $\leq$ $75 \%$ was categorized as good activity criteria. In cycle II there was an increase in student learning activity, and it was categorized as quite high and reached good criteria $(22.58 \%)$ in this research. In cycle II, the number of active students reached 28 students $(90.32 \%)$. This was because the students had already had learning experience with the touch media application in the previous cycle. In addition, this cycle II percentage had met the good criteria in this study.

Mathematics learning outcome of twodimensional figure circumference and wide material after touch media implementation also increased when it was compared with the research result in cycle I. Here, the mastery learning increased to $58.06 \%$ (I8 students), but it had not mastered yet from this research $\geq 80 \%$ student complete). In cycle II, it increased again to $83.87 \%$ (26 students) and the percentage was mastered from this research. The increase in learning result indicates that students are getting better in understanding two-dimensional figure circumference and wide material.

First, it is recommended that teacher needs to prepare the required materials that are fun and colorful. Also, it would be better if all touch media are made by the teachers themselves. Teacher should create a learning media by utilizing the items existed in the environment around the school. Second, time management for learning implementation should be in accordance with the planned allocation. In addition, it is better for teacher to give an understanding on the benefit and use, as well as about the game rule of touch media to students. The purpose is to make each player can perform the tasks appropriately according to the role. Finally, teacher should prepare the tools and facilities better as a support in learning activity.

\section{Acknowledgment}

No acknowledgment

\section{References}

Ariani, N.F. (2016). Penerapan metode inkuiri terbimbing berbantuan media manipulatif untuk memahamkan konsep pecahan sederhana pada siswa kelas iii sdn besowo 5 kecamatan kepung kabupaten kediri. Unpublisher Thesis. Malang: Graduate Program of Universitas Negeri Malang.

Arsyad, A. (2013). Media pembelajaran. Depok: Rajagrafindo Persada

Hanah, R. (2016). Penggunaan bahan manipulatif untuk memahamkan materi peluang pada siswa smp dengan pendekatan pendidikan matematika realistik. Unpublished Thesis. Malang: Graduate Program of Universitas Negeri Malang.

Kemendikbud Direktorat Jenderal Pendidikan Dasar Dan Menengah Direktorat Pembinaan Sekolah Dasar: 2017

National Council of Teachers of Mathematics. (2000). Principles and Standards for School Mathematics. Reston, VA: National Council of Teachers of Mathematics.

Perdana, A. (2014). Pengertian, fungsi, dan contoh bahan manipulatif. (Online) (http://hirarkiinside.blogspot.co.id/2014/08/pe 
ISSN 2580-2135

ngertian-fungsi-dan-contoh-media.html) diakses 06 April 2017.

Sarnoko. (2016). Penerapan pendekatan savi berbantuan video pembelajaran untuk meningkatkan aktivitas dan hasil belajar ips siswa kelas iv sdn i sanan girimarto wonogiri. Unpublished Thesis. Malang: Graduated Program of Universitas Negeri Malang.

Susilo, H., Chotimah, H., \& Sari, Y.D. (2012). Penelitian tindakan kelas. Malang: Bayumedia Publishing 
ISSN 2580-2135 